\title{
PENGARUH LUAS PENAMPANG WADAH TERHADAP BESARNYA REDUKSI VOLUME SAMPAH ORGANIK RUMAH TANGGA MENGGUNAKAN LARVA LALAT BLACK SOLDIER FLY
}

\author{
Bayu Chondro Purnomo, Nurjazuli, Suhartono \\ (Fakultas Kesehatan Masyarakat Universitas Diponegoro)
}

\begin{abstract}
This research is Quasi experimental with the Post Only Group Design method. This study uses the amount of maggot and organic waste with a ratio of 1:2, with 1/2 $\mathrm{kg}$ of maggot against $1 \mathrm{~kg}$ of garbage, with a volume of $6000 \mathrm{~cm} 3$ containers and a variation of the cross sectional variation of $20 \times 20 \mathrm{~cm} 2$ with a height of $15 \mathrm{~cm}$, the cross section area of $30 \times 20 \mathrm{~cm} 2$ with a height of $10 \mathrm{~cm}$ and $10 \mathrm{~cm}$ and the cross section area of $30 \times 40 \mathrm{~cm} 2$ with a height of 5 $\mathrm{cm}$. Based on the results of the research that has been made, the waste reduction by BSF larvae, the cross-sectional area of $20 \times 20 \mathrm{~cm}$ was $516.7 \mathrm{gr}$, the cross-sectional area of $30 \times 20$ $\mathrm{cm}$ was $555.6 \mathrm{gr}$, while the cross-section area of $30 \times 40 \mathrm{~cm}$ was $644.4 \mathrm{gr}$. The highest reduction is obtained from the cross-sectional area of $30 \times 40 \mathrm{~cm}$. Based on the results of the normality test it obtained the value of $P$-Value $>\alpha(0.05)$. This indicates that the data is distributed normally by looking at the variant difference test, obtained a value of $p$-value $0.049(<\alpha)$. Then it can be concluded that there is an influence between cross-sectional area and waste reduction by BSF larvae. The wider cross-section of the garbage container, the easier BSF larvae reduce organic waste.
\end{abstract}

Keywords: Black Soldier Fly (Hermetia Illucens); waste reduction; cross-sectional area

\begin{abstract}
Abstrak
Penelitian ini merupakan penelitian eksperimen semu dengan metode Post Only Group Design. Penelitian ini menggunakan jumlah maggot dan sampah organik dengan perbandingan $1: 2$, dengan $1 / 2 \mathrm{~kg}$ maggot terhadap $1 \mathrm{~kg}$ sampah, dengan volume wadah $6000 \mathrm{~cm} 3$ dan variasi penampang variasi $20 \times 20 \mathrm{~cm} 2$ dengan tinggi $15 \mathrm{~cm}$, luas penampang $30 \times 20 \mathrm{~cm} 2$ dengan tinggi $10 \mathrm{~cm}$ dan $10 \mathrm{~cm}$ dan luas penampang $30 \times 40 \mathrm{~cm} 2$ dengan tinggi $5 \mathrm{~cm}$. Berdasarkan hasil penelitian yang telah dilakukan, pengurangan sampah oleh larva $B S F$, luas penampang $20 \times 20 \mathrm{~cm}$ adalah $516,7 \mathrm{gr}$, luas penampang $30 \times 20 \mathrm{~cm}$ adalah 555,6 gr, sedangkan luas penampang $30 \times 40 \mathrm{~cm}$ adalah 644,4 gr. Reduksi tertinggi diperoleh dari luas penampang $30 \times 40 \mathrm{~cm}$. Berdasarkan hasil uji normalitas diperoleh nilai $P$-Value > $(0,05)$. Hal ini menunjukkan bahwa data berdistribusi normal dengan melihat uji beda varian, diperoleh nilai p-value $0,049(<\alpha)$. Maka dapat disimpulkan bahwa ada pengaruh antara luas penampang dan pengurangan sampah oleh larva BSF. Semakin lebar penampang wadah sampah, semakin mudah larva BSF mereduksi sampah organik.
\end{abstract}

Kata Kunci : Lalat Prajurit Hitam (Hermetia Illucens); pengurangan limbah; Iuas penampang

\section{PENDAHULUAN}

Sampah organik yang dihasilkan masyarakat dengan jumlah yg banyak akan dampak terhadap lingkungan, maka perlu adanya pengolahan yang tepat agar sampah organik bisa teratasi dengan baik. Pengolahan sampah organik yang sudah dilakukan dengan dikonversi menjadi pupuk kompos dan biogas. Selain diolah menjadi kompos dan biogas, daur ulang sampah organik dapat dilakukan dengan metode biokonversi. Biokonversi adalah suatu 
proses yang melibatkan mikroorganisme seperti jamur, ragi, bakteri dan larva untuk mengubah sampah organik menjadi produk yang bernilai tinggi. ${ }^{1}$ Konsep biokonversi dapat menjadi solusi mengatasi masalah pengelolaan sampah organik. Biokonversi merupakan proses berkelanjutan yang memanfaatkan larva serangga untuk mentransformasi sampah organik. Selanjutnya larva tersebut mengkonversi nutrisi dari sampah dan disimpan sebagai biomassanya. Dalam hal ini, serangga Diptera dengan spesies: Hermetia illucens. ${ }^{1}$

Black Soldier Fly (BSF) atau Hermetia illucens merupakan spesies lalat yang dapat mendegradasi sampah organik dengan memanfaatkan larvanya yang akan mengekstrak energi dan nutrien dari sampah sayuran, sisa makanan, bangkai hewan, dan kotoran sebagai bahan makanannya. ${ }^{2}$ Lava BSF yang biasa disebut Maggot dapat berkembangbiak walaupun dalam lingkungan yang tidak wajar, seperti media/ sampah yang banyak mengandung kadar garam, alkohol, asam dan ammonia. Maggot tidak mati namun maggot tersebut menjadi fakum/ tidak aktif, jika udara lingkungan sangat dingin atau kekuranan makanan dan akan aktif jika cuaca menjadi hangat kembali atau makanan sudah tersedia. Siklus hidup maggot berlangsung kurang lebih 12 hari tergantung pada kondisi lingkungan dan makanannya ${ }^{3}$.

Maggot dapat mengkonversi limbah organik menjadi biomassa yang lebih sederhana, serta mampu mengurangi massa sampah mencapai 52\%-56\%. Sehingga maggot dapat dijadikan solusi untuk mengurangi sampah organik. Selain itu, maggot juga dapat hidup dalam toleransi $\mathrm{pH}$ yang cukup tinggi, tidak membawa gen penyakit, mempunyai kandungan protein yang cukup tinggi (40-50\%), dan mudah dibudidayakan., ${ }^{4,5}$ Maggot mampu mengkonsumsi sampah makanan dalam jumlah besar lebih cepat dan lebih efisien dibandingkan spesies lain yang diketahui. Hal ini dipengaruhi oleh bagian mulutnya dan enzim pencernaannya yang lebih aktif. ${ }^{2}$ Pola makan maggot juga memiliki ciri tersendiri yaitu maggot bergerak untuk mencari makanan secara horizontal ${ }^{6}$.

Pengolahan sampah organik menggunakan BSF dan langkah kerjanya menyebutkan bahwa jumlah sampah yang dapat dikonsumsi oleh maggot dibatasi oleh ketebalan lapisan sampah tersebut. Maggot dapat memakan secara keseluruhan media makanan pada bagian dasar penampang dengan ketebalannya sekitar $5 \mathrm{~cm}$. Jika melebihi ketebalan tersebut menyebabkan tidak optimalnya kerja maggot dalam mengurai sampah pada penampang wadah. $^{7}$

Penelitian ini menggunakan variasi luas penampang wadah sampah organik yang akan diolah oleh maggot, dengan variasi $20 \times 20 \mathrm{~cm}^{2}, 20 \times 30 \mathrm{~cm}^{2}$, dan $30 \times 40 \mathrm{~cm}^{2}$. Menggunakan volume sampah dan jumlah maggot yang sama. Sehingga akan diperoleh ketebalan sampah yang berbeda pada setiap penampang wadah. Berdasarkan kondisi tersebut penulis tertarik melakukan penelitian dengan tujuan untuk menganalisis pengaruh luas penampang wadah untuk mengolah sampah dengan menggunakan larva lalat BSF (Black 
Soldier Fly) /(Hermetia Illucens) terhadap besarnya reduksi volume sampah organik rumah tangga.

\section{METODE PENELITIAN}

Penelitian yang digunakan adalah Quasi Experimental dengan metode Post Only Group Design dengan maksud untuk mengetahui ada atau tidak adanya pengaruh luas penampang terhadap reduksi volume sampah sebelum diberi perlakuan dengan maggot BSF dan sesudah diberi perlakuan dengan maggot BSF. Sampah yang digunakan dalam penelitian ini, yaitu sampel sampah organik yang berada di TPA Purwokerto. Penelitian ini menggunakan jumlah maggot dan sampah dengan perbandingan 1:2, dengan 1/2 kilogram maggot terhadap 1 kilogram sampah, dengan volume wadah $6000 \mathrm{~cm}^{3}$ dan menggunakan 3 macam unit percobaan diantaranya perlakuan dengan luas penampang $20 \times 20 \mathrm{~cm}^{2}$ dengan tinggi $15 \mathrm{~cm}$, luas penampang $30 \times 20 \mathrm{~cm}^{2}$ dengan tinggi $10 \mathrm{~cm}$ dan luas penampang $30 \times 40$ $\mathrm{cm}^{2}$ dengan tinggi $5 \mathrm{~cm}$. Alat pengumpulan data yang dipakai dalam penilitian ini adalah soil meter, thermometer dan timbangan. Waktu Penelitian dilakukan Pada Bulan September - Oktober 2021.

\section{HASIL PENELITIAN}

Pengukuran suhu dilakukan setiap hari sebanyak 3 kali sehari selama 7 hari menggunakan thermometer. Hasil uji parameter suhu penelitian dapat dilihat pada gambar dibawah ini.

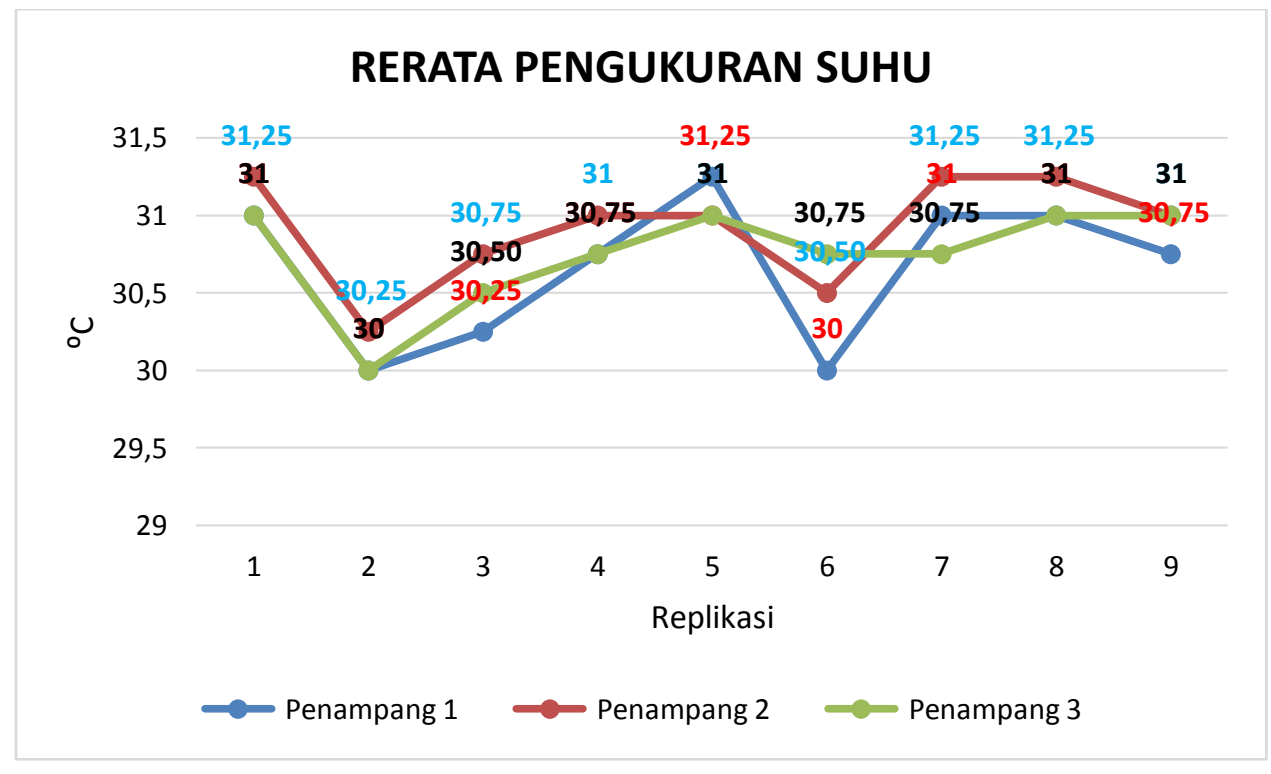

Gambar 1. Rerata Pengukuran Suhu

Berdasarkan hasil pengamatan suhu, diperoleh suhu rata-rata sebesar $31^{\circ} \mathrm{C}$, dengan suhu maksimum sebesar $31,25{ }^{\circ} \mathrm{C}$ dan suhu minimum sebesar $30{ }^{\circ} \mathrm{C}$. Pengukuran 
kelembaban dilakukan 3 kali dalam sehari menggunakan soil tester. Hasil uji parameter kelembaban penelitian dapat dilihat pada gambar dibawah ini :

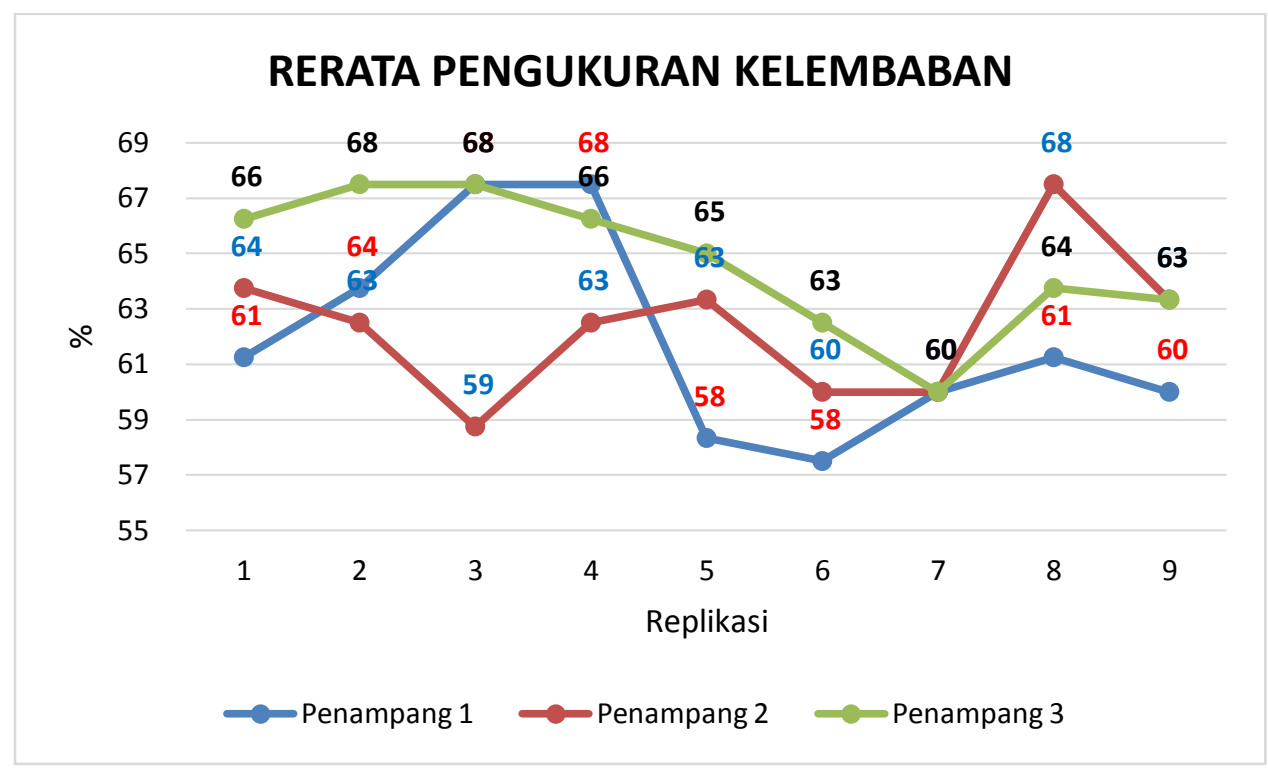

Gambar 2. Rerata Pengukuran Kelembaban

Berdasarkan hasil pengamatan kelembaban, diperoleh rerata kelembaban maksimum sebesar $68 \%$ dan kelembaban minimum sebesar $58 \%$. Hasil residu sampah pada setiap pengukuran dapat dilihat pada gambar 4.di bawah ini :

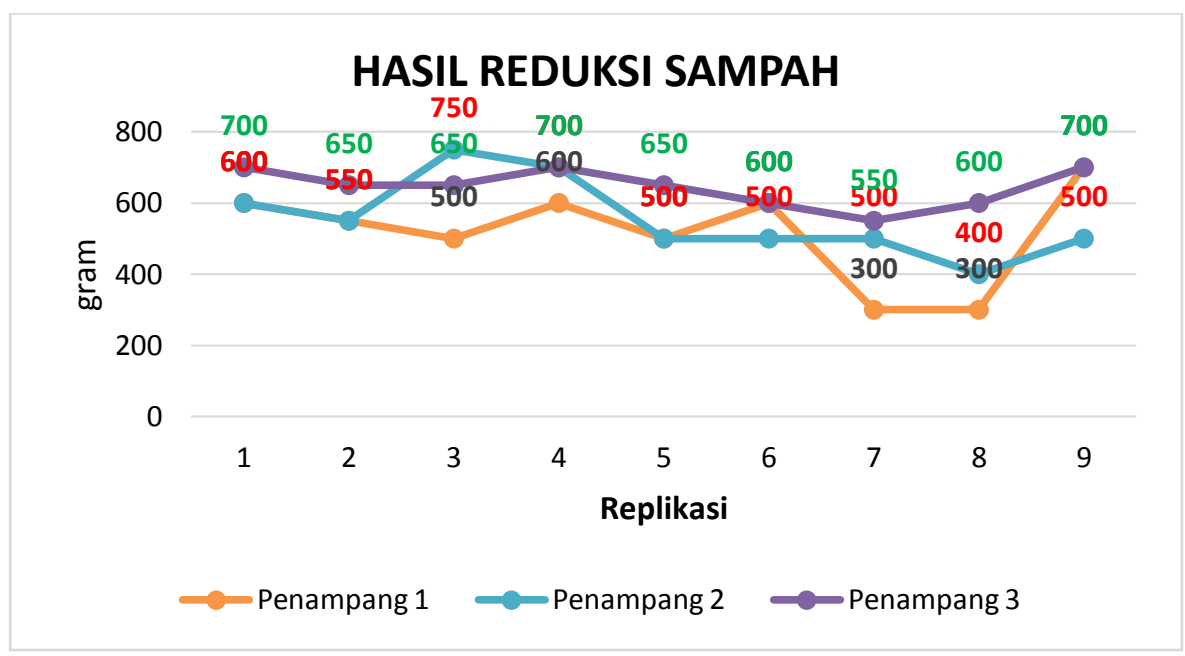

Gambar 3. Hasil Reduksi Sampah

Berdasarkan hasil penelitian yang telah dilakukan diperoleh jumlah residu sampah oleh larva BSF seperti pada tabel berikut ini. 
Tabel 1. Hasil Reduksi Sampah oleh Larva BSF

\begin{tabular}{|c|c|c|c|c|c|}
\hline No & $\begin{array}{c}\text { Variasi } \\
\text { Luas } \\
\text { Penampang } \\
(\mathrm{cm})\end{array}$ & $\begin{array}{c}\text { Jumlah } \\
\text { Sampah } \\
\text { Awal (gr) }\end{array}$ & Replikasi & $\begin{array}{c}\text { Residu } \\
\text { Sampah } \\
\text { (gr) }\end{array}$ & $\begin{array}{c}\text { Rata-rata } \\
\text { Residu } \\
\text { Sampah (gr) }\end{array}$ \\
\hline \multirow[t]{9}{*}{1.} & $20 \times 20$ & 1000 & I & 600 & \\
\hline & & & II & 550 & \\
\hline & & & III & 500 & \\
\hline & & & IV & 600 & \\
\hline & & & V & 500 & 516.7 \\
\hline & & & VI & 600 & \\
\hline & & & VII & 300 & \\
\hline & & & VIII & 300 & \\
\hline & & & IX & 700 & \\
\hline \multirow[t]{9}{*}{2.} & $30 \times 20$ & 1000 & I & 600 & \\
\hline & & & II & 550 & \\
\hline & & & III & 750 & \\
\hline & & & IV & 700 & \\
\hline & & & V & 500 & 555.6 \\
\hline & & & VI & 500 & \\
\hline & & & VII & 500 & \\
\hline & & & VIII & 400 & \\
\hline & & & IX & 500 & \\
\hline \multirow[t]{9}{*}{3.} & $30 \times 40$ & 1000 & I & 700 & \\
\hline & & & II & 650 & \\
\hline & & & III & 650 & \\
\hline & & & IV & 700 & \\
\hline & & & V & 650 & 644.4 \\
\hline & & & VI & 600 & \\
\hline & & & VII & 550 & \\
\hline & & & VIII & 600 & \\
\hline & & & IX & 700 & \\
\hline
\end{tabular}

Dari tabel 1 dapat diketahui bahwa hasil residu sampah setelah perlakuan pada luas penampang 20x20 cm sebanyak $516.7 \mathrm{gr}$, luas penampang $30 \times 20 \mathrm{~cm}$ sebanyak $555.6 \mathrm{gr}$, sedangkan luas penampang $30 \times 40 \mathrm{~cm}$ sebanyak $644.4 \mathrm{gr}$. Berdasarkan hasil tersebut dapat diambil nilai residu tertinggi diperoleh dari luas penampang $30 \times 40 \mathrm{~cm}$.

Uji normalitas dilakukan untuk melihat apakah data tersebut terdistribusi secara normal. Hasil uji normalitas dapat dilihat pada tabel di bawah ini : 
Tabel 2. Hasil Uji Normalitas

\begin{tabular}{lcccc}
\hline & Variasi Luas & \multicolumn{3}{c}{ Shapiro - Wilk } \\
\cline { 2 - 5 } & $\begin{array}{c}\text { Penampang } \\
\text { Sampah }\end{array}$ & Statistik & df & Sig. \\
\hline Pengaruh & Var 1 $(20 \times 20)$ & .874 & 9 & .136 \\
\cline { 2 - 5 } Sampah & Var 2 $(30 \times 20)$ & .898 & 9 & .240 \\
\cline { 2 - 5 } Organi & Var 3 (30x40) & .889 & 9 & .194 \\
\hline
\end{tabular}

Penelitian ini menggunakan uji normalitas Shapiro-wilk, berdasarkan tabel di atas diketahui bahwa PValue diantaranya :

a. Penampang 1 memiliki nilai $p$-value yakni 0,136 ,

b. Penampang 2 memiliki nilai $p$-value yakni 0,240,

c. Penampang 3 memiliki nilai $p$-value yakni 0,194.

Sehingga dapat disimpulkan PValue ketiga variable tersebut $>\alpha(0,05)$, dan data dinyatakan berdistribusi normal. Sehingga data dilakukan Uji beda varian menggunakan One Way Anova.

\section{a. Uji One Way Anova.}

Penelitian ini dilanjutkan dengan melihat apakah terdapat perbedaan pada pengaruh luas penampang wadah terhadap besarnya reduksi volume sampah organik menggunakan larva BSF. Penelitian ini dapat dilanjutkan dengan menggunakan uji Anova dan dapat dilihat pada tabel di bawah ini:

Tabel 3. Hasil uji Anova

\begin{tabular}{lcrllll}
\hline & \multicolumn{2}{l}{ Sum } & of & \multicolumn{2}{l}{ Mean } & \\
& Squares & df & Square & F & Sig. \\
\hline Between Groups & 77222.222 & 2 & 38611.111 & 3.439 & .049 \\
\hline Within Groups & 269444.444 & 24 & 11226.852 & & \\
\hline Total & 346666.667 & 26 & & & \\
\hline
\end{tabular}

Berdasarkan tabel diatas menunjukkan nilai sig (signifikansi) sebesar 0,049. Hasil signifikasi ini dapat diartikan < a $(0,05)$. Sehingga dapat disimpulkan HO ditolak yang berarti ada pengaruh luas penampang wadah terhadap besarnya reduksi volume sampah organik menggunakan larva BSF.

Untuk mengetahui pengaruh yang paling dominan dari ketiga varian luas penampang yang digunakan larva BSF dalam mereduksi sampah organik, dilanjutkan menggunaka uji Post Hoc, dapat dilihat pada tabel 4.di bawah ini. 
Tabel 4. Uji Post Hoc

\begin{tabular}{|c|c|c|c|c|c|c|}
\hline \multirow{2}{*}{$\begin{array}{c}\text { (I) Variasi } \\
\text { Luas } \\
\text { Penampang } \\
\text { Sampah }\end{array}$} & \multirow{2}{*}{$\begin{array}{c}\text { (J) Variasi } \\
\text { Luas } \\
\text { Penampang } \\
\text { Sampah }\end{array}$} & \multirow{2}{*}{$\begin{array}{c}\text { Mean } \\
\text { Difference } \\
(\mathrm{I}-\mathrm{J})\end{array}$} & \multirow[b]{2}{*}{$\begin{array}{l}\text { Std. } \\
\text { Error }\end{array}$} & \multirow[b]{2}{*}{ Sig. } & \multicolumn{2}{|c|}{ 95\% Confidence Interval } \\
\hline & & & & & Lower Bound & Upper Bound \\
\hline \multirow[t]{2}{*}{$\begin{array}{l}\text { Var 1 } \\
(20 \times 20)\end{array}$} & $\begin{array}{c}\text { Var } 2 \\
(30 \times 20)\end{array}$ & -38.889 & 49.949 & .444 & -141.98 & 64.20 \\
\hline & $\begin{array}{c}\operatorname{Var} 3 \\
(30 \times 40)\end{array}$ & $-127.778^{*}$ & 49.949 & .017 & -230.87 & -24.69 \\
\hline \multirow[t]{2}{*}{$\begin{array}{l}\text { Var } 2 \\
(30 \times 20)\end{array}$} & $\begin{array}{c}\operatorname{Var} 1 \\
(20 \times 20)\end{array}$ & 38.889 & 49.949 & .444 & -64.20 & 141.98 \\
\hline & $\begin{array}{c}\operatorname{Var} 3 \\
(30 \times 40)\end{array}$ & -88.889 & 49.949 & .088 & -191.98 & 14.20 \\
\hline \multirow[t]{2}{*}{$\begin{array}{l}\text { Var } 3 \\
(30 \times 40)\end{array}$} & $\begin{array}{c}\text { Var 1 } \\
(20 \times 20)\end{array}$ & $127.778^{*}$ & 49.949 & .017 & 24.69 & 230.87 \\
\hline & $\begin{array}{c}\operatorname{Var} 2 \\
(30 \times 20)\end{array}$ & 88.889 & 49.949 & .088 & -14.20 & 191.98 \\
\hline
\end{tabular}

Pada tabel di atas didapatkan hasil tersebut uji post hoc berikut ini :

a. Variasi 1 terhadap Variasi 2 tidak terdapat beda penurunan secara statistik (Pvalue $(0.444)>\alpha(0.05))$

b. Variasi 2 terhadap Variasi 3 tidak terdapat beda penurunan secara statistik ( $P$ value $(0.08)>\alpha(0.05))$

c. Variasi 1 terhadap Variasi 3 terdapat beda penurunan secara signifikan ( $P$-value $(0.017)<\alpha(0.05))$

d. Nilai Negatif (-127.778) pada Uji Var.1 terhadap Var.3, menandakan nilai reduksi pada Var.3 > dari pada Var.1.

Dari data hasil residu yang dihasilkan, didapatkan persentase reduksi pada tabel 5. berikut ini :

Tabel 5. Persentase Reduksi Sampah oleh Larva BSF

\begin{tabular}{ccc}
\hline No & Luas Penampang & Persentase Reduksi (\%) \\
\hline 1 & Penampang 1 (20x20) & 51,67 \\
\hline 2 & Penampang 2 (30x20) & 55,56 \\
\hline 3 & Penampang 3 (30x40) & 64,44 \\
\hline
\end{tabular}

Dari tabel 5. dapat diketahui bahwa persentase reduksi tertinggi pada variasi luas penampang 1 (20x20) dan Penampang $3(30 \times 20) \mathrm{cm}^{2}$. Hasil dari reduksi diukur masanya untuk mengetahui besar persentase yang tersisa dari proses reduksi. Persentase reduksi sampah ditentukan dari jumlah sampel sampah yang diberikan dan dimakan oleh Larva BSF dikali 100\%. 


\section{PEMBAHASAN}

Berdasarkan hasil penelitian yang dilakukan menunjukkan kondisi suhu sampel sampah cukup baik untuk pembiakkan larva BSF karena masih mendekati suhu optimum pertumbuhan larva. Dari semua hasil pengukuran suhu, tidak ada yang melewati batas maksimum suhu larva dapat hidup. Sehingga dapat dikatakan bahwa sampel sampah memiliki suhu yang sesuai dengan kebutuhan larva untuk hidup dan makan. Larva akan menjadi tidak aktif pada suhu kurang dari $10^{\circ} \mathrm{C}$ dan suhu lebih tinggi dari $45^{\circ} \mathrm{C}$, di mana kelangsungan hidup mereka menurun drastis. Jika terlalu panas, larva akan keluar dari sumber makanannya untuk mencari tempat yang lebih dingin. Jika terlalu dingin, metabolisme larva menjadi lebih lambat, akibatnya larva makan lebih sedikit sehingga pertumbuhannya pun menjadi lambat ${ }^{2}$. Suhu pada pertumbuhan larva BSF pada penelitian ini berpengaruh cukup baik. Hal tersebut karna larva yang digunakan berada pada fase aktif yakni larva yang berumur 20-25 hari. Larva juga sudah lebih beradaptasi sehingga dapat melakukan proses degradasi sampah yang akan digunakan larva sebagai sumber nutrisi ${ }^{8}$.

Rata-rata maksimum kelembaban sebesar $68 \%$ dan minimum sebesar $58 \%$. Hasil pengukuran menunjukkan kondisi kelembaban cukup konstan. Konstannya kelembaban dintaranya $60-70 \%{ }^{2}$. Suhu media cukup baik untuk pembiakan larva BSF karena masih mendekati suhu optimum pertumbuhan larva, yaitu antara $30^{\circ} \mathrm{C}-36^{\circ} \mathrm{C}^{9}$. Hal ini dikarenakan larva BSF bersifat sangat mudah dehidrasi, sehingga dibutuhkan kelembaban udara yang cukup $^{10}$.

Larva BSF tidak memiliki jam istirahat, namun larva juga tidak makan sepanjang waktu. Kadar air optimum pada makanan larva BSF adalah 60-90\% ketika kadar air sampah yang diberikan terlalu tinggi akan menyebabkan larva keluar dari reaktor pembiakan, mencari tempat yang lebih kering. Namun ketika kadar airnya juga kurang akan mengakibatkan konsumsi makanan yang kurang efisien ${ }^{11}$. Sementara suhu makanan yang diberikan optimum pada angka $27-33^{\circ} \mathrm{C}$ namun pada suhu yang lebih rendah larva BSF tetap dapat bertahan karena adanya asupan panas dari sampah yang dimakannya ${ }^{11}$

Berdasarkan hasil penelitian yang telah dilakukan, reduksi sampah oleh larva BSF luas penampang 20x20 cm sebanyak 516,7 gr, luas penampang $30 \times 20 \mathrm{~cm}$ sebanyak 555,6 gr, sedangkan luas penampang $30 \times 40 \mathrm{~cm}$ sebanyak $644,4 \mathrm{gr}$. Berdasarkan hasil tersebut dapat diambil nilai residu tertinggi diperoleh dari luas penampang $30 \times 40 \mathrm{~cm}$.

Dari hasil uji normalitas data reduksi sampah oleh larva BSF di peroleh nilai $p$-value $>\alpha$ $(0,05)$. Hal ini menandakan bahwa data terdistribusi dengan normal. Dilanjutkan dengan melihat nilai uji beda varian, diperoleh nilai $p$-value 0,049 $(<\alpha)$. Maka dapat di simpulkan bahwa terdapat pengaruh antara luas penampang dengan reduksi sampah oleh larva BSF. Semakin luas penampang wadah sampah maka semakin mudah larva BSF mereduksi sampah organik ${ }^{12}$. 
Reduksi sampah dapat diukur dari perbedaan berat awal sampah dan berat akhir yang telah diberikan kepada larva BSF dalam setiap penampang yang digunakan. Selain itu pertumbuhan panjang dan berat larva akan mecerminkan reduksi sampah. Ada beberapa faktor yang menjadi penentu nilai rekdusi sampah yaitu tingkat kematian larva, keadaan lingkungan, dan jenis makanan yang diberikan kepada larva BSF. Larva akan mengkonsumsi makanan yang disukai seperti sampah yang bertekstur lunak, rendah serat dan bernutrisi ${ }^{13}$.

Penelitian yang dilakukan oleh Rukmini Piyantina, dkk dengan judul pengolahan sampah organik untuk budidaya maggot BSF diperoleh hasil bahwa 1,5-2 kilogram maggot dapat mereduksi sampah sebanyak 3-4 kilogram sampah per hari. Hal ini menjelaskan bahwa jumlah maggot terhadap jumlah sampah yang dapat direduksi yaitu 1:2 per hari ${ }^{14}$.

Berdasarkan penelitian sebelumnya larva BSF dapat dimanfaatkan bioreduktor sampah organik untuk melengkapi penguraian sampah organik konvensional yang selama ini mengandalkan mikroba ${ }^{15}$. Secara gambaran, bioreduksi sampah oleh maggot dapat menyisakan sampah organik berupa padatan dan lindi. Padatan selanjutnya diolah dengan mengandalkan mikroba yang disebut biocomposting yang akhirnya dapat dimanfaatkan sebagai pupuk organik. Sementara lindi atau cairan dari bioreduksi maggot dapat dimanfaatkan langsung sebagai pupuk cair. Kemampuan larva BSF dalam memproses sampah organik dipengaruhi oleh makronutrisi sampah organik, mikroba dan pengontrolan makanan, beberapa mempelajari fisiologi, mikrobiologi, dan proses biokimia ${ }^{15}$.

\section{SIMPULAN DAN SARAN}

Perlakuan dalam penelitian ini dilaksanakan dengan tiga perlakuan luas penampang yang berbeda $(20 \times 20 \mathrm{~cm}, 20 \times 30 \mathrm{~cm}, 30 \times 40 \mathrm{~cm})$ dengan replikasi 9 kali.. Pengamatan dilakukan sebanyak tiga kali selama tujuh hari dengan melihat reduksi sampah organik menggunakan larva BSF. Berdasarkan hasil tersebut dapat diambil nilai reduksi tertinggi diperoleh dari luas penampang $30 \times 40 \mathrm{~cm}$. Maka dapat disimpulkan bahwa terdapat pengaruh antara luas penampang dengan jumlah reduksi sampah organik oleh larva BSF. Semakin luas penampang wadah sampah maka semakin mudah larva BSF mereduksi sampah organik. Diharapkan penelitian berikutnya dapat berinovasi dalam mengurangi dampak bau yang di hasilkan selama proses reduksi sampah organik

\section{DAFTAR PUSTAKA}

1. Salman N, Nofiyanti E, Nurfadhilah T. Pengaruh dan Efektivitas Maggot Sebagai Proses Alternatif Penguraian Sampah Organik Kota di Indonesia. J Serambi Eng. 2019;5(1):83541.

2. Sipayung PYE. Pemanfaatan Larva Black Soldier Fly ( Hermetia Illucens ) Sebagai Salah 
Satu Teknologi Reduksi Sampah Utilization of the Black Soldier Fly ( Hermetia Illucens ) Larvae As a Technology Option for Urban Solid Waste Reduction. Tugas Akhir Jur Tek Lingkung Fak Tek Sipil Dan Perenc Inst Teknol Sepuluh Nop Surabaya. 2015;130.

3. Darmawan M, Sarto, Agus P. "Budidaya Larva Black Soldier Fly ( Hermetia lllucens .) Dengan Pakan Limbah Dapur ( Daun Singkong )." Simp Nas 1. 2017;208-13.

4. Suciati $R$, Faruq $H$. EFEKTIFITAS MEDIA PERTUMBUHAN MAGGOTS Hermetia illucens (Lalat Tentara Hitam) SEBAGAI SOLUSI PEMANFAATAN SAMPAH ORGANIK. Biosf J Biol dan Pendidik Biol. 2017;2(1):0-5.

5. Rizki S, Hartami P, Erlangga E. Tingkat densitas populasi maggot pada media tumbuh yang berbeda. Acta Aquat Aquat Sci J. 2017;4(1):21.

6. Nisrani N. PENGARUH JENIS PAKAN TERHADAP KERAGAAN DAN MORTALITAS LARVA BLACK SOLDIER FLY (Hermetia illucens L.). 2021. 1-55 p.

7. Alamgir M, Khulna University of Engineering and Technology. WasteSafe., WasteSafe 2011 (2nd: 2011 : Khulna B. Proceedings of the executive summary WasteSafe 2011 : 2nd International Conference on Solid Waste Management in Developing Countries, Khulna, Bangladesh February 13-15, 2011. 2011;52(February):275.

8. Kinasih I, Suryani Y, Astri Yuliawati. Konversi Limbah Organik oleh Lava Lalat Tentara Hitam (Hermetia illucens) Menjadi Sumber Protein Terbarukan Bagi Produksi Pakan Ternak Organik. Lap Akhir Penelit. 2017;116-8.

9. Mutiar S, Yulhendri. Pengolahan sampah organik dengan larva black soldier fly ( Hermetia illucens ). Sci Technol. 2020;5:59-63.

10. Saragi ES. Penentuan Optimal Feeding Rate Larva Black Soldier Fly (Hermetia illucens) dalam Mereduksi Sampah Organik Pasar. Ekp. 2015;13(3):1576-80.

11. Arief Sabdo Yuwono PDM. Black Soldier Fly ( BSF ) Penggunaan Larva ( Maggot) Dalam Pengolahan Limbah Organik. 2018. 1-88 p.

12. Pathiassana MT, Izzy SN, Nealma S. Study of Feed Rate on Bioconversion Process With Variation of Waste Types Managed by Biomagg International Synergy Using Black Soldier Fly Larva (Hermetia illucens). Tambora [Internet]. 2020;4(1):56. Available from: mega.trishuta@uts.ac.id

13. Rofi DY, Auvaria SW, Nengse S, Oktorina S, Yusrianti Y. Modifikasi Pakan Larva Black Soldier Fly (Hermetia illucens) sebagai Upaya Percepatan Reduksi Sampah Buah dan Sayuran. J Teknol Lingkung. 2021;22(1):130-7.

14. Rukmini Piyantina, Luthfiana Rozak Dinda WS. Pengolahan Sampah Organik untuk Budidaya Maggot Black Soldier Fly (BSF). 2020. 250-253 p.

15. Fauzi M, Muharram LH. Karakteristik Bioreduksi Sampah Organik oleh Maggot BSF ( Black Soldier Fly ) pada Berbagai Level Instar: Review. J Sci Technol Enterpreneursh. 2019;1(2):134-9. 